\title{
Apropos of Accounting Information Indicators as Determinants of Cash Dividend Policy Decision: A Comparative Study on Amman Stock Exchange (2001-2013)
}

\author{
Thair A. Kaddumi ${ }^{1} \&$ Qais A. Al-Kilani ${ }^{1}$ \\ ${ }^{1}$ Finance and Banking Science Department, Applied Science Private University, Amman, Jordan \\ Correspondence: Thair A. Kaddumi, Finance and Banking Science Department, Applied Science Private \\ University, P.O. Box 166 Postal Code 11931, Amman, Jordan. Tel: 962-795-004-334: E-mail: \\ thair_lion@asu.edu.jo or lion_kanoosh@yahoo.com
}

Received: January 30, 2015

Accepted: February 11, 2015

Online Published: March 25, 2015

doi:10.5539/ijef.v7n4p135

URL: http://dx.doi.org/10.5539/ijef.v7n4p135

\begin{abstract}
Investor's psychological behavior normally seek to invest in companies that are characterized by stable and positive dividend stream. Dividend policy is related to the decision of whether to distribute or not to distribute cash to shareholder. This type of decision is not taken in isolation from other related financial factors, as such decision is considered an integrated part of the company's overall financial decisions. This study aims at investigating the apropos of accounting information indicators (financial indicators) and their role in determining cash dividend policy adopted by companies listed within the major sectors of Amman Stock exchange. Extracting the accounting information indicators pertaining to the three main sectors (Banking, Industrial and Services) of ASE, and by applying the simple linear regression statistical approach, the results indicated that the dividend policy adopted by the three sectors were mainly determined by accounting information indicators and that the impact of these indicators on cash dividend policy vary due to dissimilarity of the sectors' nature, whereas the results pointed out that different indicator affect different sector, which means that the impact of the accounting information is not identical on cash dividend policy decision.
\end{abstract}

Keywords: dividend policy, indicators, sectors, accounting information, ASE

\section{Introduction}

The term dividend can take different forms - cash dividend, stock dividend and dividend repurchase were the company can buy a portion of its outstanding stocks from securities market. The decision of whether a company should distribute all its net profit as dividends, or to plow back all or certain portion of it for the purpose of reinvestment, is a significant decision. As if the company is aiming at pleasing the shareholder they will go with high dividend rate, but such decision might tend to be costly if the company is going to seek external finance to fund its future investment plans. But, low dividend rate or no dividend at all will refrains expected investors from acquiring such companies' shares, especially short term investors who are attracted by current returns.

Various dividend theories have been introduced in an attempt explain how dividend policy decisions are concluded and whether they have an influence on the firm value. Some of the approaches were conservative that support that the increase in dividend payment will lead to an increase in the company's value, while other groups do believe that it will affect the company's value adversely, and the group who stand in the middle believe that it has no effect on company's value (Anupam, 2012). This was first introduced by Modigliani and Miller in 1961 in which they opposed the idea that dividend payment, were perfect market exist has no effect on firms value-which is called irrelevant theory. While (Al-Makawi, 2007) confirmed that dividend payment do have an impact on the company's value-relevant theory, which was suggested by Myron J. Gordon and John linter.

Baker (2009), stated that dividend decision do affect the amount of returns to be distributed to shareholders in the form of cash dividend and the amount of profit to be retained, thus dividend policy is mainly concerned with determining the amount and pattern of cash payment to shareholders during certain time horizon. Generally speaking, Financial managers are supposed to take many important decisions related to investment, financing and development in an effort to increase company's market value (Afza \& Mirza, 2011). Moreover mangers have to decide as how much of the company's end of year profit should be distributed among shareholders and how 
much percentage should be retained for reinvestment.

Cash dividend policy is judged as one of the major issues that were addressed at large scale topics in modern financial literature. Dividend policy does play a significant and remarkable role in determining corporate market value. Thus dividend policy behavior tendency is affected by internal factors such as cash flow, investment opportunities, liquidity and profitability of the company, and also its affected by external factor such as economic macro factors, economic stability and growth, technological changes and governmental rules and regulation (Roberto, 2002).

Amman Stock Exchange - ASE is considered as the only market in Jordan where securities (Common Stocks and Bonds) are traded. Selection of ASE was due to the fact that the market has witnessed a remarkable changes and events especially during the last 10 years that affected dramatically the performance of all companies listed in the market, and these events may be attributed to 2008 financial crisis or the political issues in countries surrounding Jordan. As a result of these events, many corporations profitability was adversely affected, which means decline in corporations cash flow and as a consequence to this cash dividend policy adopted by the various number of corporations listed in ASE will be affected.

Based on the above mentioned discussion, this study will focus on the financial factors (indicators) that may or may not affect corporation's dividend decision policy. The study will be conducted on a comparative basis between the three major sectors of ASE - banking sector, industrial sector and services sector for the period (2001-2013). The main goals of this research is to determine as which independent factor (financial / accounting indicators) may impact dividend policy decision and to identify whether or whether not the industry type do have any influence on dividend decision policy?

\section{Theoretical Framework}

Company's end of year profits can be either distributed in the form of dividend to shareholders or re-invested in the company in different forms as per the company's requirements, such as for capitalization purpose.

Dividend payment decision is tied-up with many parties involved that may be affected by such decision, parties such as - shareholders, management, lenders as well as suppliers. Conflict between these parties interests do prevail, as shareholders prefer to be paid the highest possible dividend ratio as they are the only recipient of cash dividend, while creditors they prefer that companies profit is better to be plowed back into the company so the company will not default installment payment on due time. From the company's management point of view they also in favor of retaining end of year profit in order to be able to meet and absorb the consequences of unexpected events and circumstances, and also to equip them with more capabilities in grapping investments opportunities.

Profit may be considered as the main and ultimate determinant of the company's capacity in dividend payment. In previous empirical researches many factors have been recognized to impact company's dividend payment decisions. Numbers of factors have been identified in previous empirical studies to influence the dividend policy decisions of the firm. Profit is regarded as the major indicator of the firm's capacity to pay dividends. According to (Lintner, 1956) on his study on manger's dividend policy in USA, he found that current year profit and previous year profit do affect dividend decision. Miller \& Modigliani (1961) argued that dividend policy decision is irrelevant to companies' value. It is rather affected by investment decision under perfect market theory, this was asserted by (Ang \& Ciccone, 2009). Gordon (1963) nullified Miller \& Modigliani argument by presenting his Bird in hand assumption, as increase in dividends rate will influence shareholder wealth positively because of market uncertainty and imperfect information.

\section{Literature Preview}

Ross et al. (2007) has defined dividend as that part of payment made out of the company's after tax profit to the company's owner in the form of stock dividend or cash dividend. While (Lease et al., 2000) has defined dividend policy as the practice of management that is adopted in deciding dividend payout ratio, which means the pattern and amount of cash distribution to the company's owners.

The most common type of dividend is a cash dividend. A public company's board of directors determines the amount of the firm's dividend. The board sets the amount per share that will be paid and decides when the payment will occur.

Cash Dividend policy has been discussed and investigated by many researchers, in an attempt to dig into the factors and determinants that define corporate cash policy strategy. Lintner (1956) has discussed many financial and non-financial factors that determine corporate cash dividend policy, (Rozeff, 1982); (Baker \& Powell, 1999) studied the influence of costs - transaction costs and agency costs in comparison to external financing on the 
firm's dividend decision of a firm. He pointed out that there should be a balance between transaction costs and agency costs in order to achieve an optimum cash dividend policy. While (Fama, 1974) discussed financial theories that is related to trade-off between investment and financing opportunities. (Han at el., 1999) investigated cash dividend behavior based on the theory of agency cost as well as tax-based theory. (Easterbrook, 1984; Jensen, 1986), supported the existence of relationship between ownership structure and dividend policy is attributed to "Agency problem", that was first discussed its relation to dividend policy by (Rozeff, 1982) and (Easterbrook, 1984).

Alkuwar (2009), Anil and Kapoor (2008) pointed out that the company profitability ratio reflected a very strong and statistically significant determinant of dividend ratio. (Carlson, 2001) has investigated into some variables that may have an impact on dividend decisions. In his study he pointed out that Stock repurchase only explains a small portion of the decrease in dividend yield and that an increase in the retained earnings and investment opportunities may also explain the reason behind decrease in dividend yield.

Ho (2002) in his comparative study between Australia and Japan found that dividend decision is influenced positively by company size in Australia and by liquidity in Japan but in both countries industry has a major effect.

(Ahmed \& Javad, 2009) on their research on 320 companies listed in KSE indicated that companies with positive and stable earnings are paying higher dividend, also they indicated that ownership concentration and company's liquidity have a strong positive influence on dividend payment. (Arnott \& Asness, 2012) on their research on American Stock Markets, concluded that higher aggregate dividend payment ratio ratios were associated with higher future earnings growth expectation. In another study by (Nuhu et al., 2014) on financial and non-financial companies in Ghanaian market they found that dividend payout ratio is mainly affected by leverage, profitability, board size and tax rate.

AL-Shubiri (2011) studied the dividend policy behavior within the industrial sector in Amman Stock Exchange -ASE, and found that factors such as profitability, growth opportunities and the companies size increase the opportunity of paying dividend, while assets liquidity and free cash flow -FCF has no significant effect on dividend payment.

Musiega at el. (2013) investigated the determinants of dividend policy for non-financial sector companies listed in Nairobi securities exchange, as they found that ROE, Company's current earnings and companies rate of growth are positively correlated to dividend decision policy.

Arif and Akbar (2013) in their attempt to identify and evaluate dividend policy determinants on non-financial companies listed in Pakistan - Karachi securities market, they identified that the most significant determinants to dividend policy are attributed to profitability, size, tax and investments opportunities.

Hossain et al. (2014) search into company specific oriented factors impact on dividend payout ratio decision in Dhaka Stock Exchange (Bangladesh), they found that company's profitability reflect a positive and significant effect on dividend payout ratio while earning volatility and ownership do have a negative significant influence on dividend payment decision and factors such as growth opportunities, company's size and company's liquidity didn't explain any change in dividend policy payment adopted by the company.

Previous literatures have discussed dividend policy from different aspects (financial and non-financial), and the different results they concluded were contradicting with each others, and this may be attributed to the specific nature of each market and the period of the study, as some of the previous studies were conducted on developed market while other studies were performed in developing or emerging market and this for sure will lead to different conclusion. Nevertheless of this, many studies agreed mainly on profitability as one of the major determinants of cash dividend policy.

\section{Major Determinants of Dividend Policy}

Company's dividend rate decision is considered as one of the most important decisions taken by financial management. The main objective of dividend decision is to maximize ownership wealth. There were many attempt adopted by various researchers as an endeavor to try to find out the mystery that conceal dividend policy determinants. Brealey and Myers (2005) described dividend decision as one of the most difficult top ten unsolved dilemma in financial management. This description comes in consistency with Black (1976) who mentioned that "The harder we look at the dividend picture, the more it seems like a puzzle, with pieces that don't fit together". Thus there was no consensus on the exact factors that have significant effect on dividend policies According to these various literatures and studies, some of the most important determinants of dividend policy decision can be summarized as follow. 


\subsection{Profitability}

Company's profitability is a critical factor that determine dividend ratio, as higher is the profitability of the company will increase the opportunity of dividend payment, in order to reflect its sound and solid financial position, this is considered as the main concern for both investor to measure their return on investment and for shareholder to measure their holding reward. According to Baker et al. (2006); Ahmed and Javad (2009) asserted that stability of current earnings plays as a major determinant of dividend payout ratio. This positive relationship between profitability and dividend policy was supported by Ho (2003) and Aivazian et al. (2003).

\subsection{Leverage}

Leverage plays a main role in defining company's dividend policy. Aivazian et al. (2003) stated that companies with low leverage rate are more willing to pay dividend than other companies with higher debt ratio, as higher leverage ratio will weaken the company's capability in paying dividend, as they have to retain profit to serve debts dues.

\subsection{Company Size}

Company's size is a major factor that demonstrate cash dividend policy. As large sized companies are characterized by an easy access to financial market to obtain the required finance, so they tend to rely less on internally generated funds, this will allow them to pay higher dividend amount. This type of relationship between dividend payout ratio and company's size is supported by the transaction cost explanation of dividend payment policy (Chang \& Rhee, 1990).

\subsection{Investment Opportunity}

It represent the company's option to adopt any future investment and growth opportunities. Therefore the higher are investment and growth opportunities, the higher will be the need for financial resources, this means higher retention rate and lower dividend rate.

\subsection{Tax Rate}

Investors in general don't prefer high dividend rate if tax bracket levied on dividend is high, instead they tend to search for capital gain, so in general tax rate have an adverse effect on dividend rate. Fortunately, in Jordan share dividend as well as shares' capital gain are tax exempted in order to encourage foreign investors. As higher the tax rate on share dividend than on capital gain will lead to decline in dividend payout ratio (Casey \& Dickens, 2000).

\subsection{Liquidity}

Another major determinant of dividend payout ratio is company's liquidity position. (Anupam, 2012) on his study on UAE companies and (Hafeez \& Attiya, 2008) on their study on Karachi non-financial listed companies found that liquidity is considered as the most significant determinant of dividend policy decision and it poses a statistically positive impact on dividend policy decision. Companies' with higher liquidity ratio are more capable of paying high dividend rate more than companies with poor liquidity stand.

\subsection{Legal Constraints}

This mainly related to protecting the right of creditors. In general, countries' rules and regulations inhibit companies that are characterized with high liabilities rate or insolvent or going into bankruptcy from paying cash dividend, as it may affect adversely its ability to meet its overdue debts.

\subsection{Ownership Consideration}

Bokpin (2011) stated that the larger the size of board membership, the higher is dividend rate that is paid to shareholders. Ownership consideration is tackled from three dimensions the first one is the tax status of the company's owners, as if they have a large income they will prefer low dividend rate, the second one is big owners investment opportunities, whether it seems that they can earn more than what if they reinvested the amount in the company in this case they will vote for higher dividend rate, while the third and last dimension, the dilution of ownership as high dividend rate will attract more investor which may lead to ownership dilution.

\section{Amman Stock Exchange}

It was called Amman Financial Market - AFM which was established during 1976 and started its active operation on January 1978, since then the AFM witnessed a remarkable development and progress as secondary market trading rose from J.D. 7.8 million (\$11.00 million) in 1978 and reached J.D. 3.00 billion (\$ 4.23 billion) in 2013, also the number of listed companies rose from 68 companies in 1978 to 240 companies by end of year 2013. In 1999 AFM was divided into three major bodies - Amman Stock Exchange - ASE, Securities Depository Center 
and Jordan Securities Commission. Table 1 below high lights the progress that ASE witnessed during last 12 years (2002-2013) related to number of listed companies and its market value:

Table 1. Number of listed companies and its market value (million US Dollar) during 2002-2013

\begin{tabular}{|c|c|c|c|c|c|c|c|c|c|c|c|c|}
\hline Year & 2002 & 2003 & 2004 & 2005 & 2006 & 2007 & 2008 & 2009 & 2010 & 2011 & 2012 & 2013 \\
\hline $\begin{array}{l}\text { No. of listed } \\
\text { companies }\end{array}$ & 258 & 161 & 192 & 201 & 227 & 245 & 262 & 272 & 277 & 247 & 243 & 240 \\
\hline $\begin{array}{l}\text { Listed Companies } \\
\text { market value }\end{array}$ & 7,091 & 10,960 & 18,378 & 37,600 & 29,720 & 41,192 & 35,822 & 31,763 & 30,820 & 27,175 & 26,990 & 25,710 \\
\hline
\end{tabular}

Source: Amman Stock Exchange Annual Reports.

\section{Research Hypothesis}

Since the previous factors may or may not affect and determine the dividend policy decision of Jordanian corporations, and as Amman Stock Exchange (ASE) is still considered as emerging market in which these effects may vary from one sector to another, the best way to express the research problem is by phrasing the following two main hypotheses:

$\mathbf{H}_{1}$ : Dividend policy of Jordanian Corporations is determined by accounting information indicators.

$\mathbf{H}_{2}$ : Impacts of accounting information indicators on dividend policy vary from one sector to another.

\section{Research Methodology}

When we talk about Dividend policy, dividend size or dividend pattern we are coming across the most debatable issue that have been discussed by a large number of researchers and academicians. It was debated from two point of view, first one it was discussed as the dividend policy effect on some financial indicators and the other point of view was the search for the factors / variables whether financial or non-financial that affect dividend policy decision. The argument that we rely on within this study based on the concept that if the company can't or don't have the capacity to reinvest its earning in order to generate earning that overtop its cost of capital, so it's better for the company to distribute its earning amongst its shareholder in the form of dividend.

The study is based on a comparative statistical analysis taking into account all companies that paid cash dividend during the study period (2001-2013). The said companies are listed in three sectors (Banking Sector, Industrial Sector and Service Sector. These sector are the major three sectors of ASE as they constitute the major portion of the total securities market value. Table -2 below illustrate the percentage of each of the three sectors to the total market value of ASE for the last 10 years:

Table 2. \% of each of the three sectors to the total market value (2004-2013)

\begin{tabular}{lcccccccccc}
\hline Year & $\mathbf{2 0 1 3}$ & $\mathbf{2 0 1 2}$ & $\mathbf{2 0 1 1}$ & $\mathbf{2 0 1 0}$ & $\mathbf{2 0 0 9}$ & $\mathbf{2 0 0 8}$ & $\mathbf{2 0 0 7}$ & $\mathbf{2 0 0 6}$ & $\mathbf{2 0 0 5}$ & $\mathbf{2 0 0 4}$ \\
\hline \% of Service Sector Market Value & $18 \%$ & $18 \%$ & $18 \%$ & $17 \%$ & $17 \%$ & $14 \%$ & $14 \%$ & $14 \%$ & $20 \%$ & $19 \%$ \\
\% of Industrial Sector Market Value & $24 \%$ & $32 \%$ & $31 \%$ & $29 \%$ & $27 \%$ & $24 \%$ & $21 \%$ & $16 \%$ & $5 \%$ & $26 \%$ \\
\% of Banking Sector Market Value & $50 \%$ & $44 \%$ & $44 \%$ & $46 \%$ & $47 \%$ & $50 \%$ & $53 \%$ & $57 \%$ & $62 \%$ & $54 \%$ \\
\% of Total Three Sectors & $\mathbf{9 2 \%}$ & $\mathbf{9 3 \%}$ & $\mathbf{9 3 \%}$ & $\mathbf{9 1 \%}$ & $\mathbf{9 0 \%}$ & $\mathbf{8 8 \%}$ & $\mathbf{8 8 \%}$ & $\mathbf{8 6 \%}$ & $\mathbf{8 7 \%}$ & $\mathbf{9 8 \%}$ \\
\hline
\end{tabular}

Source:- Appendix 1.

\section{Data Analysis and Statistical Approach}

In order to measure how dividend policy is determined, several accounting information indicators were calculated and used for this study purposes, the study's indicators are calculated for the period (2001-2013) based on the annual reports pertaining to corporations listed in ASE that are affiliated to the three major sectors.

- The accounting indicators are divided into two major variables: ( Refer to Appendix - 2, A, B \&C for variables values): First the independent variables that consist of the following indicators:

- Fixed Assets / Total Assets - FTA,

- Earnings per share - EPS (End of Year profit / No. of Outstanding Stocks),

- Book value per share - BV (Equity Rights / No. of Outstanding Stocks), 
- Price earnings ratio- P/E (Market Value Per Stock / EPS),

- Price/book value - P/B (Market Value Per Stock / BV),

- Return on assets - ROA (End of Year profit / Total Assets),

- Return on equity - ROE (End of Year profit / Equity Rights),

- Company's leverage / Debt ratio - LVR (Long term liabilities / Total Assets),

- Natural logarithm of operational cash flow - OPC, Liquidity ratio -LQR (Cash and quasi cash / current liabilities)

While the second variable is cash dividend percentage DPs which will incorporate the study dependant variables, it's calculated as follow:

- DPS = Dividend Paid / No. of Outstanding Stocks.

Simple Linear Regression analysis is deemed as a suitable statistical approach to be employed in order to analyze whether the accounting information indicators mentioned above may or may assist decision makers in determining their dividend policy regarding Jordanian companies listed within the three sectors of the study. The aim of regression analysis is to measure the impact power of each accounting indicator on corporation's dividend policy for each sector separately, and if the same accounting indicators affect the corporation's dividend policy associated with each sector differently by each single accounting indicator.

\section{Regression Results and Discussion}

Running simple linear regression on each of the three sectors we obtain the following results.

\subsection{Services Sector Analysis and Results}

Regression analysis results showed that the $\mathrm{R}^{2}$ between the accounting indicators as independent variables and the dividend per share as dependent variable is 0.835 , which means that the accounting information indicators determine 0.835 of the behavior of Dividend policy of Jordanian Services Corporations.

The impact of accounting information indicators on dividend policy of Services sector corporations vary as illustrated in the following table 4 below:

Table 4. Service sector statistical analysis outputs

\begin{tabular}{lll}
\hline Accounting Indicator & $\mathrm{B}$ & $\mathrm{Sig} \mathrm{t}$ \\
\hline Fixed Assets/Total Assets & -0.196 & 0.066 \\
Earnings Per Share & 0.239 & 0.028 \\
Book Value Per Share & 0.096 & 0.055 \\
Price Earnings Ratio & -0.002 & 0.004 \\
Price/book Value & 0.042 & 0.020 \\
Return On Assets & 0.578 & 0.027 \\
Return On Equity & 0.353 & 0.037 \\
Debt Ratio & 0.061 & 0.494 \\
Operational Cash Flow & 0.029 & 0.005 \\
Liquidity Ratio & 0.031 & 0.536 \\
\hline
\end{tabular}

Table 4 above shows that not all the accounting information indicators do posses significant impact on dividend policy decision in relation to services sector corporations in Jordan, only those independent variables that have significance level $\leq 0.05$, in other words the accounting indicators that affect positively the dividend policy of services sector are: earning per share, price/book value, return on assets, return on equity and operational cash flow, while the price earnings ratio has negative impact on dividend policy.

\subsection{Industrial Sector Analysis and Results}

Regarding the industry sector analysis, the regression results showed that the coefficient of determination $-\mathbf{R}^{2}$ between the accounting indicators as independent variables and the dividend per share as dependent variable is 0.960 , which means that the accounting information indicators determine $96 \%$ of the behavior of Dividend policy of Jordanian Industrial Corporations.

Table 5 below demonstrate the influence of accounting information indicators pertaining to corporations listed 
within the industrial sector on dividend rate decision, as we can notice the degree of influence that vary between different variables as follow:

Table 5. Industrial sector statistical analysis outputs

\begin{tabular}{lll}
\hline Accounting Indicator & B & Sig t \\
\hline Fixed Assets/Total Assets & -0.489 & 0.106 \\
Earnings Per Share & 0.253 & 0.021 \\
Book Value Per Share & 0.089 & 0.010 \\
Price Earnings Ratio & -0.002 & 0.217 \\
Price/book Value & 0.012 & 0.672 \\
Return On Assets & 0.905 & 0.033 \\
Return On Equity & 0.531 & 0.079 \\
Debt Ratio & -0.935 & 0.011 \\
Operational Cash Flow & 0.072 & 0.059 \\
Liquidity Ratio & 0.423 & 0.007 \\
\hline
\end{tabular}

The aforementioned Table 5 above shows that there exist a significant impact of some of the accounting information indicators on dividend policy of industrial listed corporations in Jordan related to those indicators which have significance level $\leq 0.05$, which means that the accounting indicators that affect positively the dividend policy of industrial listed corporations sector are: earning per share, book value per share, return on assets, return on assets and liquidity ratio, but debt ratio (degree of leverage) do dominate a negative impact on dividend policy.

\subsection{Banking Sector Analysis and Results}

It's important to indicate that banking sector analysis outputs showed different statistical results. The regression results showed that the $\mathbf{R}^{2}$ between accounting indicators as independent variables from one side and the dividend per share as dependent variable from the other side is 0.986 , which means that the accounting information indicators determine $98.6 \%$ of the behavior of Dividend policy of Jordanian Banking Corporations. Also we can notice from Table 6 below, that debt ratio (degree of leverage) is the only variable that own a negative statistical impact on dividend decision in relation to banking sector listed companies.

The degree of influence and its range of accounting information indicators on dividend policy decision related to banking sector listed corporations also incongruous as illustrated in the following Table 6 below:

Table 6. Banking sector statistical analysis output

\begin{tabular}{lll}
\hline Accounting Indicator & B & Sig t \\
\hline Fixed Assets/Total Assets & -6.194 & 0.331 \\
Earnings Per Share & -0.118 & 0.068 \\
Book Value Per Share & -0.044 & 0.083 \\
Price Earnings Ratio & -0.001 & 0.252 \\
Price/book Value & -0.010 & 0.125 \\
Return On Assets & 3.388 & 0.067 \\
Return On Equity & -0.217 & 0.520 \\
Debt Ratio & -0.650 & 0.001 \\
Operational Cash Flow & -0.001 & 0.377 \\
Liquidity Ratio & -0.007 & 0.963 \\
\hline
\end{tabular}

The above table shows that there is only one factor significantly affecting the dividend policy of banking corporations (The debt ratio) with significance level $\leq 0.05$, this impact is negative, which means that as the debt increases the dividend per share decreases, while the other independent variables have no any significant impact on dividend policy.

Based on the above results, we can point out that the first hypothesis has been approved since the dividend policy of the three main sectors listed in Amman Stock Exchange (Services, Industry and Banking) were determined by the accounting information indicators. 
Regarding the second hypothesis, it is also approved since the results showed that the impact of accounting information indicators on dividend policy vary as the sectors vary.

\section{Conclusion}

The research concluded that the dividend policy of Jordanian Corporations is mainly determined by accounting information indicators and that the impact of accounting information indicators on dividend policy decision do contrast from one sector to another, since the dividend policy of services sector has been affected positively by earning per share, price/book value, return on assets, return on equity and operational cash flow and negatively by price earnings ratio. This is a logical result in case the company decides to pay cash dividend the impact of such decision will affect the stock price adversely which means that stock price will decline by the same rate of dividend rate. Regarding dividend decision of industrial sector which has been influenced positively by earning per share, book value per share, return on assets and liquidity ratio and negatively by debt ratio, this may be attributed to the fact that the increase in debts means an increase in risk degree which at the end if such external sources invested efficiently will lead to increase in expected return above the cost of borrowed fund and will leave for companies a reasonable amount to be distributed in the form of cash dividend. Banking sector dividend policy has been affected negatively by only debt ratio, while the effect of other indicators was insignificant. Banking sector is characterized by the fact that its main source of finance is deposits which will levy a high burden on banks in the form of debit interest to be paid for account holders as this deposit volume increases such burden will also increase which will hinder banks ability to pay high dividend. Moreover the study period do contain implicitly the effect of the financial crisis and its significant effect on financial institutions in general and banking institutions in particular, where during financial crisis period the Central Bank of Jordan directed commercial banks to increase their reserves and cut their dividend to protect themselves from unexpected events and from the financial crisis aftermath.

\section{References}

Afza, T., \& Mirza, H. H. (2011). Do Mature Companies Pay More Dividends? Evidence from Pakistani Stock Market. Mediterranean Journal of Social Sciences, 2(2), 152-161.

Ahmed, H., \& Javad, A. (2009). Dynamics and Determinants of Dividend Policy in Pakistan. International Research Journal of Finance and Economics, 28, 56-61.

Aivazian, V., Booth, 1., \& Cleary, S. (2003). Do Emerging Market Firms Follow Different Dividend Policies From U.S. Firms? Journal of Financial Research, 26(3), 371-387. http://dx.doi.org/10.1111/1475-6803.00064

Al-Kuwari, D. (2009). Determinants of the Dividend Payout Ratio of Companies Listed on Emerging Stock Exchanges: The Case of the Gulf Cooperation Council (GCC) Countries. Global Economy \& Finance Journal, 2(2), 38-63.

Al-Malkawi, H. (2007). Determinants of Corporate Dividend Policy in Jordan: An Application of the Tobit Model. Journal of Economics and Administrative Sciences, 23(2), 44-70. http://dx.doi.org/10.1108/10264116200700007

Ang, J. S., \& Ciccone, S. J. (2009). Dividend Irrelevance Theory. In K. H. Baker (Ed.), Dividends and Dividend Policy.

Anupam, M. (2012). An Empirical Analysis of Determinants of Dividend Policy - Evidence from the UAE Companies. Global Review of Accounting and Finance, 3(1), 18-31.

Arif, A., \& Akbar, F. (2013). Determinants of Dividend Policy: A Sectoral Analysis from Pakistan. International Journal of Business and Behavioral Sciences, 3(9), 16-33.

Arnott, D., \& Asness, S. (2012). Does Dividend Policy Foretell Earnings Growth? Social Science Electronic Publishing, Inc.

Baker, H. K. (2009). Dividends and Dividend Policy: An Overview. In K. H. Baker (Ed.), Dividends and Dividend policy (pp. 3-19). John Wiley \& Sons, Inc.: Hoboken, NJ. http://dx.doi.org/10.1002/9781118258408

Baker, H. K., \& Powell, G. E. (1999). How corporate Managers View Dividend Policy? Quarterly Journal of Business and Economics, 38(2), 17-27.

Baker, H. K., Mukherjee, T. K., \& Paskelian, O. G. (2006). How Norwegian managers view dividend policy. Global Finance Journal, 17(1), 155-176. http://dx.doi.org/10.1016/j.gfj.2006.06.005 
Black, F. (1976). The Dividend Puzzle. Journal of Portfolio Management, 2, 5-8.

Bokpin, G. A. (2011). Ownership Structure, Corporate Governance and Dividend Performance on the Ghana Stock Exchange. Journal of Applied Accounting Research, 12(1), 61-73. http://dx.doi.org/10.1108/09675421111130612

Carlson, J. B. (2001). Why is the Dividend Yield so Low? Federal Reserve Bank of Cleveland. Economic Commentary, (April / 2001).

Casey, K. M., \& Dickens, R. N. (2000). The Effects of Tax and Regulatory Changes on Commercial Bank Dividend Policy. The Quarterly Review of Economics and Finance, 40(2), 279-293. http://dx.doi.org/10.1016/s1062-9769(99)00051-4

Chang, R. P., \& Rhee, S. G. (1999). The Impact of Personal Taxes on Corporate Dividend Policy and Capital Structure Decisions. Financial Management, 19(2), 21-31. http://dx.doi.org/10.2307/3665631

Easterbrook, \& Frank, H. (1984). Two Agency- Cost Explanations of Dividends. American Economic Review, 74, 650-659.

Easterbrook, F. (1984). Two Agency Costs Explanations of Dividends. American Economic Review, 74, 650-659.

Fama, E. (1974). The Empirical Relationships between Dividend and Investment Decisions of Firms. American Economic Review, June, 304-314.

Gordon, M. J. (1963). Optimal Investment and Financing Policy. The Journal of Finance, 264-272.

Hafeez, A., \& Attiya, Y. (2008). Dynamics and determinants of Dividend Policy in Pakistan Evidence from Karachi Stock Exchange for Non-Financial Listed Firms. MPRA paper 37342.

Han, K. C., Lee, S. H., \& Suk, D. Y. (1999). Institutional Shareholders and Dividends. Journal of Financial and Strategic Decisions, 12(1), 53-62.

Ho, H. (2003). Dividend Policies in Australia and Japan. International Advances in Economic Research, 9(2), 91-100. http://dx.doi.org/10.1007/BF02295710

Hossain, F., Sheikh, R., \& Akterujjaman, S. M. (2014). Impact of Firm Specific Factors on Cash Dividend Payment Decisions: Evidence from Bangladesh. International Review of Business Research Papers, 10(2), 62-80.

Jensen, \& Michael, C. (1986). Agency Costs of Free Cash Flow, Corporate Finance, and Takeovers.

Lease, R. C., John, K., Kalay, A., Loewenstein, U., \& Sarig, O. D. (2000). Dividend Policy: Its Impact on Firm Value. Harvard Business School Press, Boston, MA.

Lintner, J. (1956). Distribution of Incomes of Corporations among Dividends, Retained Earnings and Taxes. The American Economic Review, 46(2), 97-113.

Miller, M. H., \& Modigliani, F. (1961). Dividend Policy, Growth, and the Valuation of Shares. The Journal of Business, 411-433. http://dx.doi.org/10.1086/294442

Musiega, M. G., Alala, O. B., Douglas, M., Christopher, M. O., \& Robert, E. (2013). Determinants of Dividend Payout Policy Among Non-Financial Firms on Nairobi Securities Exchange, Kenya. International Journal of Scientific \& Technology Research, 2(10), 253-266.

Nuhu, E., Musah, A., \& Basil, D. (2014). Determinants of Dividend Payout of Financial Firms and Non-Financial Firms in Ghana. International Journal of Academic Research in Accounting, Finance and Management Sciences, 4(3), 109-118. http://dx.doi.org/10.6007/ijarafms/v4-i3/1057

Roberto, M. A. (2002). Making Difficult Decisions in Turbulent Times: In Their Own Way, Complexity and Ambiguity Tyrannize Decision-Making. What Managers Need are Strategies for Making Clear, Accurate Judgments Under Stressful Conditions. Ivey Business Journal, 66(3), 15-20.

Rozeff, M. S. (1982). Growth, Beta and Agency Costs as Determinants of Dividend Payout Ratios. The Journal of Financial Research, 5(3), 249-259. http://dx.doi.org/10.1111/j.1475-6803.1982.tb00299.x 
Appendix A. Market Value of Stock Market \& the Main Three Sectors of ASE (US Million Dollars)

\begin{tabular}{|c|c|c|c|c|c|c|c|c|c|c|}
\hline Year & 2013 & 2012 & 2011 & 2010 & 2009 & 2008 & 2007 & 2006 & 2005 & 2004 \\
\hline ASE market Value & 25,709 & 26,990 & 27,175 & 30,820 & 31,763 & 35,823 & 41,192 & 29,720 & 37,601 & 18,378 \\
\hline Service Sector Market Value & 4,562 & 4,727 & 4,922 & 5,158 & 5,401 & 5,057 & 5,708 & 4,074 & 7,441 & 3,430 \\
\hline Industrial Sector Market Value & 6,159 & 8,700 & 8,368 & 8,820 & 8,454 & 8,560 & 8,452 & 4,671 & 1,918 & 4,761 \\
\hline Banking Sector Market Value & 12,983 & 11,788 & 12,010 & 14,098 & 14,823 & 18,043 & 21,955 & 16,793 & 23,453 & 9,854 \\
\hline
\end{tabular}

Source:- Amman Securities Depository Center.

Appendix B. A, B \& C Demonstrate the Study Variables of the Three Sectors

Table B1. Banking sector variables

\begin{tabular}{ccccccccccccc}
\hline Year & FTA & EPS & BV & P/E & PBV & ROA & ROE & LVR & LN OPCF & LQR & DPS \\
\hline 2013 & 0.013 & 0.316 & 3.26 & 12.12 & 1.17 & 0.014 & 0.097 & 0.854 & 21.36 & 0.359 & 0.153 \\
2012 & 0.014 & 0.265 & 3.18 & 13.39 & 1.11 & 0.012 & 0.083 & 0.853 & 18.77 & 0.388 & 0.143 \\
2011 & 0.013 & 0.261 & 3.25 & 14.76 & 1.18 & 0.012 & 0.080 & 0.854 & 21.16 & 0.408 & 0.144 \\
2010 & 0.014 & 0.222 & 3.34 & 21.48 & 1.42 & 0.010 & 0.066 & 0.852 & 21.04 & 0.427 & 0.128 \\
2009 & 0.013 & 0.253 & 3.39 & 20.53 & 1.53 & 0.011 & 0.075 & 0.849 & 21.79 & 0.414 & 0.117 \\
2008 & 0.012 & 0.361 & 3.32 & 18.47 & 2.01 & 0.016 & 0.109 & 0.852 & 21.34 & 0.404 & 0.142 \\
2007 & 0.011 & 0.401 & 3.80 & 24.06 & 2.54 & 0.016 & 0.106 & 0.846 & 20.27 & 0.486 & 0.163 \\
2006 & 0.011 & 0.387 & 3.68 & 21.09 & 2.22 & 0.016 & 0.105 & 0.844 & -20.85 & 0.526 & 0.149 \\
2005 & 0.012 & 0.573 & 3.85 & 32.63 & 4.86 & 0.017 & 0.149 & 0.887 & 19.19 & 0.416 & 0.097 \\
2004 & 0.012 & 0.502 & 3.75 & 24.69 & 3.30 & 0.010 & 0.104 & 0.901 & 20.92 & 0.431 & 0.097 \\
2003 & 0.013 & 0.396 & 3.94 & 21.58 & 2.17 & 0.008 & 0.086 & 0.909 & 20.46 & 0.475 & 0.106 \\
2002 & 0.014 & 0.373 & 3.71 & 13.53 & 1.36 & 0.007 & 0.086 & 0.913 & 21.08 & 0.461 & 0.118 \\
2001 & 0.014 & 0.428 & 3.66 & 13.17 & 1.54 & 0.008 & 0.099 & 0.915 & 19.86 & 0.442 & 0.100 \\
\hline
\end{tabular}

Source: Amman Stock Exchange (ASE).

Table B2. Industrial sector variables

\begin{tabular}{cccccccccccc}
\hline Year & FTA & EPS & BV & P/E & PBV & ROA & ROE & LVR & LN OPCF & LQR & DPS \\
\hline 2013 & 0.285 & 0.139 & 2.45 & 28.29 & 1.60 & 0.045 & 0.057 & 0.338 & 19.43 & 0.469 & 0.162 \\
2012 & 0.302 & 0.277 & 2.50 & 19.65 & 2.18 & 0.085 & 0.111 & 0.315 & 19.41 & 0.514 & 0.241 \\
2011 & 0.332 & 0.447 & 2.52 & 11.73 & 2.08 & 0.126 & 0.178 & 0.350 & 20.10 & 0.706 & 0.296 \\
2010 & 0.372 & 0.216 & 2.29 & 25.30 & 2.39 & 0.072 & 0.094 & 0.353 & 19.45 & 0.540 & 0.129 \\
2009 & 0.267 & 0.275 & 2.48 & 21.96 & 2.44 & 0.081 & 0.111 & 0.347 & 19.90 & 0.535 & 0.144 \\
2008 & 0.250 & 0.586 & 2.35 & 10.40 & 2.60 & 0.162 & 0.250 & 0.380 & 20.05 & 0.495 & 0.159 \\
2007 & 0.280 & 0.337 & 2.04 & 19.73 & 3.26 & 0.115 & 0.165 & 0.375 & 19.19 \\
2006 & 0.293 & 0.176 & 1.81 & 22.15 & 2.15 & 0.073 & 0.097 & 0.387 & 19.01 & 0.537 \\
2005 & 0.290 & 0.397 & 3.26 & 7.21 & 0.88 & 0.083 & 0.122 & 0.403 & 18.80 & 0.130 \\
2004 & 0.333 & 0.181 & 1.76 & 9.74 & 2.62 & 0.058 & 0.103 & 0.438 & 19.07 & 0.641 & 0.189 \\
2003 & 0.381 & 0.030 & 1.68 & 55.67 & 1.75 & 0.010 & 0.018 & 0.422 & 19.36 & 0.489 & 0.079 \\
2002 & 0.420 & 0.122 & 1.65 & 13.56 & 1.21 & 0.040 & 0.074 & 0.453 & 18.72 & 0.374 & 0.082 \\
2001 & 0.439 & 0.111 & 1.64 & 14.80 & 1.09 & 0.037 & 0.068 & 0.452 & 18.82 & 0.293 & 0.084 \\
\hline
\end{tabular}

Source: Amman Stock Exchange (ASE). 
Table B3. Services sector variables

\begin{tabular}{ccccccccccccc}
\hline Year & FTA & EPS & BV & P/E & PBV & ROA & ROE & LVR & LN OPCF & LQR & DPS \\
\hline 2013 & 0.317 & 0.100 & 1.30 & 20.00 & 1.53 & 0.046 & 0.076 & 0.661 & 18.94 & 0.170 & 0.092 \\
2012 & 0.339 & 0.128 & 1.34 & 16.03 & 1.53 & 0.052 & 0.095 & 0.636 & 19.38 & 0.170 & 0.117 \\
2011 & 0.368 & 0.071 & 1.30 & 29.28 & 1.59 & 0.035 & 0.054 & 0.628 & 18.76 & 0.182 & 0.105 \\
2010 & 0.433 & 0.116 & 1.35 & 19.16 & 1.64 & 0.050 & 0.086 & 0.555 & 19.03 & 0.254 & 0.098 \\
2009 & 0.412 & 0.128 & 1.38 & 18.53 & 1.72 & 0.054 & 0.093 & 0.541 & 20.09 & 0.356 & 0.097 \\
2008 & 0.407 & 0.122 & 1.42 & 19.98 & 1.72 & 0.053 & 0.086 & 0.548 & 19.74 & 0.354 & 0.137 \\
2007 & 0.441 & 0.130 & 1.64 & 22.97 & 1.82 & 0.050 & 0.079 & 0.534 & 19.75 & 0.374 & 0.118 \\
2006 & 0.467 & 0.119 & 1.70 & 20.58 & 1.44 & 0.045 & 0.070 & 0.533 & 19.75 & 0.420 & 0.106 \\
2005 & 0.314 & 0.289 & 1.51 & 14.55 & 2.65 & 0.122 & 0.191 & 0.371 & 19.14 & 0.705 & 0.125 \\
2004 & 0.417 & 0.166 & 1.38 & 16.83 & 1.90 & 0.068 & 0.120 & 0.431 & 19.34 & 0.509 & 0.085 \\
2003 & 0.499 & 0.094 & 1.30 & 20.20 & 1.46 & 0.039 & 0.072 & 0.462 & 19.24 & 0.444 & 0.091 \\
2002 & 0.513 & 0.047 & 1.28 & 34.35 & 1.27 & 0.020 & 0.037 & 0.464 & 18.73 & 0.260 & 0.071 \\
2001 & 0.481 & 0.032 & 1.25 & 42.19 & 1.08 & 0.013 & 0.025 & 0.473 & 17.65 & 0.323 & 0.041 \\
\hline
\end{tabular}

Source: Amman Stock exchange (ASE).

\section{Copyrights}

Copyright for this article is retained by the author(s), with first publication rights granted to the journal.

This is an open-access article distributed under the terms and conditions of the Creative Commons Attribution license (http://creativecommons.org/licenses/by/3.0/). 